\title{
Incidence trends of invasive and in situ breast cancer among females in Poland during 1999-2014
}

\section{Trendy zachorowalności na inwazyjnego i przedinwazyjnego raka piersi u kobiet w Polsce w latach 1999-2014}

\author{
Paweł Macek ${ }^{1,2}$, Dana Hashim³, Marta Mańczuk4, Ewa Błaszkiewicz, ${ }^{1,5}$, Barbara Sosnowska-Pasiarska6, \\ Małgorzata Biskup ${ }^{7,8}$, Halina Król7,9, Jolanta Smok-Kalwat ${ }^{10}$, Stanisław Góźdź7,10
}

${ }^{1}$ Department of Epidemiology and Cancer Control, Holycross Cancer Centre, Kielce, Poland Head of the Department: Paweł Macek PhD

${ }^{2}$ Faculty of Medical Sciences, School of Economics, Law, and Medical Sciences, Kielce, Poland Head of the Faculty: Grzegorz Gałuszka PhD

${ }^{3}$ Department of Preventive Medicine, Institute of Translational Epidemiology, Icahn School of Medicine at Mount Sinai, One Gustave L. Levy Place, New York, USA

Head of the Department: Emanuela Taioli MD, PhD

${ }^{4}$ Cancer Primary Prevention Unit, Department of Cancer Epidemiology, The Maria Sklodowska-Curie Memorial Cancer Centre and Institute of Oncology, Warsaw, Poland

Head of the Unit: Marta Mańczak PhD

${ }^{5}$ Department of Education, Jan Kochanowski University, Kielce, Poland

Head of the Department: Agnieszka Świerczek MA

${ }^{6}$ Department of Oncocardiology, Holycross Cancer Centre, Kielce, Poland

Head of the Department: Barbara Sosnowska-Pasiarska MD, PhD

${ }^{7}$ Faculty of Medicine and Health Sciences, Jan Kochanowski University, Kielce, Poland

Head of the Faculty: Prof. Stanisław Głuszek MD, PhD

${ }^{8}$ Department of Rehabilitation, Holycross Cancer Centre, Kielce, Poland

Head of the Department: Anna Opuchlik PhD

${ }^{9}$ Department of Didactics and Research, Holycross Cancer Centre, Kielce, Poland

Head of the Department: Halina Król PhD

${ }^{10} \mathrm{Clinic}$ of Clinical Oncology, Holycross Cancer Centre, Kielce, Poland

Head of the Clinic: Stanisław Góźdź MD, PhD, Prof. UJK

Key words: breast cancer, incidence, epidemiology, public health.

Słowa kluczowe: rak piersi, zachorowalność, epidemiologia, zdrowie publiczne.

\begin{abstract}
Introduction: Breast cancer is the most common malignant tumour among females worldwide, including low and middleincome countries. It affects $25 \%$ of the female population and yearly is diagnosed in 1.5 million women.

Aim of the research: To determine the trends and distributions for invasive and in situ breast cancer incidence rates between 1999 and 2014 in Poland overall and in the voivodeships with the greatest proportion of females aged $\geq 65$ years old. Material and methods: Data for 226,146 invasive (C50) and 7865 in situ (D05) breast cancer incidence (1999-2014) for all females was obtained from published data of the Polish National Cancer Registry (NCR). Age-standardised rates (ASRs) per $10^{5}$ person-years for all ages of combined females with $95 \%$ confidence intervals (CI) were calculated. Joinpoint regression was performed to identify log-linear trends in both invasive and carcinoma in situ incidence rates in the analysed voivodeships and in Poland overall.

Results: The ASRs of both invasive and in situ breast cancers showed increasing trends over the 1999-2014 period, with different patterns between analysed voivodeships. On average, average annual percent changes (AAPCs) varied from $1.6 \%$ to $7.9 \%$ annually, while in the Świętokrzyskie Voivodeship AAPCs remained below $0.9 \%$ annually.

Conclusions: In situ and invasive breast cancer ASRs in Poland increased between 1999 and 2014. The Annual Percentage Change have slowed since 2004 in the analysed voivodeships, but not in Poland overall. It remains uncertain if breast cancer incidence rates will continue to increase or stabilise over time.
\end{abstract}




\section{Streszczenie}

Wprowadzenie: Rak piersi jest najczęściej występującym nowotworem złośliwym u kobiet na świecie. Dotyczy 25\% populacji kobiet. Każdego roku diagnozuje się 1,5 miliona nowych zachorowań.

Cel pracy: Określenie tendencji czasowych zachorowalności na inwazyjnego i przedinwazyjnego raka piersi w latach 19992014 w Polsce oraz w województwach o najwyższym odsetku kobiet w wieku $\geq 65$ lat.

Materiał i metody: Dane o 226146 zachorowaniach na inwazyjnego (C50) i 7856 zachorowaniach na przedinwazyjnego (D05) raka piersi pochodziły z Krajowego Rejestru Nowotworów (KRN). Obliczono standaryzowane wg wieku współczynniki zachorowalności (ASR) wyrażone na $10^{5}$ osobolat z 95-procentowym przedziałem ufności (CI). Zastosowano regresję Joinpoint $\mathrm{w}$ celu określenia tendencji log-liniowych trendów zachorowalności na inwazyjnego i przedinwazyjnego raka piersi w analizowanych województwach i w Polsce.

Wyniki: W latach 1999-2014 ASR dla inwazyjnego i przedinwazyjnego raka piersi wykazywały tendencję wzrostową ze zmiennymi wzorcami zachorowalności w analizowanych województwach. Średnia roczna zmiana procentowa (AAPC) wahała się od 1,6\% do 7,9\%, natomiast w województwie świętokrzyskim pozostawała na poziomie poniżej 0,9\%.

Wnioski: W Polsce w latach 1999-2014 trendy czasowe zachorowalności na inwazyjnego i przedinwazyjnego raka piersi wykazywały tendencję wzrostową. W analizowanych województwach roczne zmiany procentowe zwolniły od 2004 r. Tendencji tej nie obserwowano w Polsce ogółem. Obserwowane zmiany estymatorów parametrów populacyjnych nie pozwalają na określenie wzorców zachorowalności na raka piersi w najbliższych latach.

\section{Introduction}

Breast cancer is the most common malignant tumour among females worldwide, including low and middle-income countries [1]. It affects $25 \%$ of the female population and was diagnosed in 1,676,633 women, age standardised rate (ASR): $43.3 / 10^{5}$ worldwide in 2012 [2]. Breast cancer incidence differs in various regions of the world, ranging from $26.8 / 10^{5}(10,922$ new cases) in Central Africa to $96.0 / 10^{5}$ (161,529 new cases) in Western Europe. The breast cancer incidence rate in Poland was 51.9/105 (17,259 diagnosed cases) for 2012, placing it among the medium-risk countries. Although Polish age-standardised incidence rates were about 1.7-times lower than in countries in western Europe, incidence rates were higher than in Central and Eastern European neighbouring countries [3].

After the Population Breast Cancer Early Detection Program was implemented in 2006, breast cancer screening programs in Poland were established nation-wide [4]. Most likely, as a result of increased screening, there has since been a reported increase in the number of ductal carcinoma in situ (DCIS) [5] and invasive early-stage breast cancer cases. Given that the comparison of 5-year relative survival rate values is often used as an indicator of early detection and treatment efficacy in breast cancer rate reduction [5], EUROCARE 5 data estimated the 5-year survival relative rate for women at $81.8 \%$ for Europe, but $71.6 \%$ for Poland (2000-2007) [6].

Poland is divided into 16 principal administrative regions (called voivodeships) and has an estimated population of 38.5 million (2013) [7]. In recent decades, there have been significant changes in the age structure of the Polish population; the population aged 65 and above increased to comprise approximately $15 \%$ (5.7 million) of the total population for the year 2013. Of those individuals age 65 and above, nearly 3.5 million were women (61\%) [7]. This new age distribution implies a rising number of cancer-re- lated deaths as well as substantially increased cancer care costs and complexity of care in the coming years.

\section{Aim of the research}

Given a lower 5-year survival rate compared to other European countries, the aim of this study was to determine the trends and distributions for invasive and in situ breast cancer incidence rates between 1999 and 2014 in Poland overall and in voivodeships with the greatest proportion of females aged $\geq 65$ years old.

\section{Material and methods}

\section{Study area and study design}

Breast cancer incidence rates (1999-2014) were calculated among women living in voivodeships with the greatest proportion of females aged $\geq 65$ years old. At least $19 \%$ of the women in the aforementioned voivodeships were over 65 years old. The percentage of this subpopulation for Poland overall is $17.6 \%$. A total of 7 selected voivodeships was included (Figure 1) [8].

\section{Data sources}

Data for invasive (C50) and in situ (D05) breast cancer incidence (1999-2014) for all females was obtained from published data of the Polish National Cancer Registry (NCR) [9]. The analysis included information on invasive (C50) and in situ (D05) breast cancer cases coded according to the International Statistical Classification of Diseases and Related Health Problems ICD-10. The data regarding the population number within voivodeships and Poland overall were determined by the current place of residence, in all ages combined, and in 18 5 -year age groups, starting from the age of 0 to 85 years and older, was also obtained from the NCR in Poland.

\section{Ethics statement}

This study is based on secondary data from the NCR. All of the presented information has been of- 


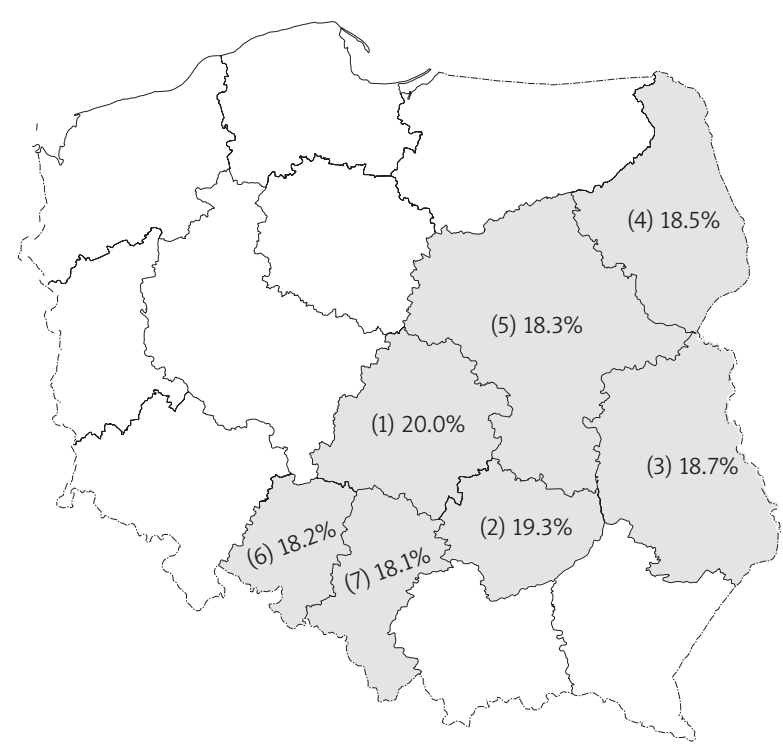

Figure 1. Voivodeships selected for incidence trend analysis were those in which the percentage of the female population $\geq 65$ years old is over $18 \%$ ( 1 - Łódź, 2 - Świętokrzyskie, 3 - Lublin, 4 - Podlasie, 5 - Mazovia, 6 - Opole, 7 - Silesia; the percentage of females $\geq 65$ years old for the whole of Poland is $17.6 \%$ ) [8]

ficially published on the NCR website and patients' consent was not required for accessing data because all data was anonymised.

\section{Statistical analysis}

Age-standardised rates (ASRs) per 100,000 personyears for all ages combining females with $95 \%$ confidence intervals (CI) for both invasive cancer and breast cancer in situ were calculated [10]. Standardisation was performed according to the age distribution of the world standardised population using the direct method [11]. Joinpoint regression was performed to identify statistically significant log-linear trends in both invasive and carcinoma in situ incidence rates in each voivodeship and in Poland overall. This method uses Monte Carlo permutation tests, with Bonferroni adjustment for multiple comparisons of significant joinpoints [12]. The Annual Percentage Change (APC) within each joinpoint segment was estimated with corresponding 95\% confidence intervals (CI). The slope of the trend line corresponds to the value and direction of the APC incidence rates. For incidence trends in which more than one slope was identified, the average annual percent change (AAPC) from 1999 to 2014 (when available) was calculated based on the geometric mean of the APC trends [13] under the assumption of a constant rate of change. When this assumption does not hold over the entire time interval, the trend may be characterized using the annual per cent changes from segmented analysis (sAPCs).

Although some breakpoints contained statistically significant nonlinear changes in trend slopes with one to three joinpoints, most trends were linear with the smallest number of breakpoints equal to zero. Trend indication and APC assessment enabled the determination of the speed of breast cancer incidence changes among women (Tables 1, 2). In order to avoid an autocorrelation error, we decided to "fit model uncorrelated errors". The program assumes that the random errors in the regression model were correlated and the regression coefficients estimated by ordinary least squares. From the trend analysis of in situ breast cancer, we excluded years of diagnosis with no cases of incidence.

Statistical analyses and graphic representations were conducted using Microsoft Office 2013, SAS Enterprise Guide version 7.1, and Joinpoint Regression Program version 4.0 (available from NCI, Bethesda, MD) [12].

\section{Results}

During 1999-2014, 234,011 cases of breast cancer were diagnosed in Polish women (226,146 - invasive breast cancer and 7865 - in situ breast cancer). Seven out of a total of 16 voivodeships were analysed with the number of cases totalling 108,777 (105,064 - invasive breast cancer and 3713 - in situ breast cancer). These constituted $46.4 \%$ of the total number of new breast cancer cases during 1999-2014 in Poland (46.4\% of the total invasive breast cancers and $40.3 \%$ of in situ breast cancers in Poland).

Incident cases of both invasive and in situ breast cancer increased in the voivodeships with a high proportion of women aged $\geq 65$ years and in Poland overall. In 1999, the prevalence of in situ breast cancer varied from $0.0 \%$ (in Łódź, Lublin, Opole, Podlasie) to $2.5 \%$ (in Mazovia). Between 1999-2005 the ratio of carcinoma in situ versus invasive cancers increased to $6.8 \%$ (in 2005 in Świętokrzyskie). From 2006 onwards the ratio of in situ vs. invasive breast cancer increased to $8.6 \%$ (in 2014 in Świętokrzyskie). This suggests an effect of early detection by the screening program implemented in Poland from 2007. Within the total time period (1999-2014) the ratio of in situ vs. invasive breast cancer ranged from 1.2\% (in Łódź) to $5.8 \%$ (in Świętokrzyskie), with an average of 3.3\% (not shown).

The ASR of invasive breast cancer among Polish women ranged from 42.1 in 1999 to 55.8 in 2014. Among women in analysed voivodeships and by year, the lowest invasive breast cancer ASRs were 18.1 (in 1999, Łódź Voivodeship) and highest 60.9 (in 2014, Łódź Voivodeship) (Table 3).

The ASRs of in situ breast cancer among women in Poland ranged from 0.3 (in 1999) to 3.4 (in 2014). Among women in analysed voivodeships, the lowest ASRs were 0.0 per 100,000 (in several years in various voivodeships) and the highest was 4.4/100,000 (in 2014, Świętokrzyskie Voivodeship) (Table 4). 
Table 1. Joinpoint regression analysis of incidence of invasive (C50) breast cancer among women in selected voivodeships and in Poland overall, 1999-2014

\begin{tabular}{|c|c|c|c|c|c|c|c|}
\hline \multirow{2}{*}{$\begin{array}{l}\text { Voivo- } \\
\text { deship }\end{array}$} & \multicolumn{2}{|c|}{ Trend 1} & \multicolumn{2}{|c|}{ Trend 2} & \multicolumn{2}{|c|}{ Trend 3} & \multirow{2}{*}{$\begin{array}{c}\text { Full range } \\
\text { AAPC }(95 \% \mathrm{Cl})\end{array}$} \\
\hline & Years & APC $(95 \% \mathrm{CI})$ & Years & APC $(95 \% \mathrm{CI})$ & Years & APC $(95 \% \mathrm{Cl})$ & \\
\hline $\begin{array}{l}\text { Święto- } \\
\text { krzyskie }\end{array}$ & 1999-2001 & $4.4(-9.0,19.8)$ & 2001-2004 & $-6.0(-16.7,6.1)$ & 2004-2014 & $2.4^{\wedge}(1.8,2.9)$ & $0.9(-1.7,3.5)$ \\
\hline Mazovia & 1999-2014 & $1.9^{\wedge}(1.5,2.3)$ & - & - & - & - & $1.9^{\wedge}(1.5,2.3)$ \\
\hline Silesia & 1999-2014 & $1.6^{\wedge}(1.0,2.1)$ & - & - & - & - & $1.6^{\wedge}(1.0,2.1)$ \\
\hline Łódź & 1999-2001 & $31.1^{\wedge}(4.9,63.8)$ & 2001-2006 & $9.4^{\wedge}(4.1,14.9)$ & 2006-2014 & $1.8^{\wedge}(0.2,3.4)$ & $7.9^{\wedge}(4.7,11.1)$ \\
\hline Lublin & 1999-2001 & $24.4(-9.3,70.5)$ & 2001-2014 & $1.8^{\wedge}(0.7,2.8)$ & - & - & $4.5^{\wedge}(0.6,8.6)$ \\
\hline Opole & 1999-2014 & $2.1^{\wedge}(1.4,2.7)$ & - & - & - & - & $2.1^{\wedge}(1.4,2.7)$ \\
\hline Podlasie & 1999-2014 & $1.6^{\wedge}(0.9,2.4)$ & - & - & - & - & $1.6^{\wedge}(0.9,2.4)$ \\
\hline Poland & 1999-2014 & $2.0^{\wedge}(1.7,2.4)$ & - & - & - & - & $2.0^{\wedge}(1.7,2.4)$ \\
\hline
\end{tabular}

$A P C$ - Annual Percentage Change, AAPC - Average Annual Percentage Change, $\mathrm{Cl}$ - confidence interval, ^(APC/AAPC) is significantly different from zero at $\alpha=0.05 ; 95 \% \mathrm{Cl}(A P C / A A P C)$ is corresponding with $95 \%$ confidence intervals.

Table 2. Joinpoint regression analysis of incidence of in situ (D05) breast cancer among women in selected voivodeships and in Poland overall, 1999-2014

\begin{tabular}{|c|c|c|c|c|c|c|c|}
\hline \multirow{2}{*}{$\begin{array}{l}\text { Voivo- } \\
\text { deship }\end{array}$} & \multicolumn{2}{|c|}{ Trend 1} & \multicolumn{2}{|c|}{ Trend 2} & \multicolumn{2}{|c|}{ Trend 3} & \multirow{2}{*}{$\begin{array}{c}\text { Full range } \\
\text { AAPC }(95 \% \mathrm{Cl})\end{array}$} \\
\hline & Years & $\mathrm{APC}(95 \% \mathrm{Cl})$ & Years & $\mathrm{APC}(95 \% \mathrm{Cl})$ & Years & $\mathrm{APC}(95 \% \mathrm{Cl})$ & \\
\hline $\begin{array}{l}\text { Święto- } \\
\text { krzyskie }\end{array}$ & 2001-2004 & $\begin{array}{c}114.8^{\wedge} \\
(34.7,242.6)\end{array}$ & 2004-2014 & $\begin{array}{c}3.9 \\
(-1.5,9.5)\end{array}$ & - & - & $\begin{array}{c}22.8^{\wedge} \\
(11.2,35.7)\end{array}$ \\
\hline Mazovia & 1999-2014 & $\begin{array}{c}5.3^{\wedge} \\
(3.8,7.0)\end{array}$ & - & - & - & - & $\begin{array}{c}5.3^{\wedge} \\
(3.8,7.0)\end{array}$ \\
\hline Silesia & 1999-2002 & $\begin{array}{c}-7.2 \\
(-21.8,10.1)\end{array}$ & 2002-2014 & $\begin{array}{c}17.2^{\wedge} \\
(15.5,18.9)\end{array}$ & - & - & $\begin{array}{c}11.9^{\wedge} \\
(8.3,15.5)\end{array}$ \\
\hline Łódź & 2004-2014 & $\begin{array}{c}8.2^{\wedge} \\
(4.9,11.6)\end{array}$ & - & - & - & - & $\begin{array}{c}8.2^{\wedge} \\
(4.9,11.6)\end{array}$ \\
\hline Lublin & 2002-2004 & $\begin{array}{c}186.2 \\
(-11.6,826.4)\end{array}$ & 2004-2014 & $\begin{array}{c}2.8 \\
(-2.3,8.3)\end{array}$ & - & - & $\begin{array}{c}22.0^{\wedge} \\
(2.9,44.6)\end{array}$ \\
\hline Opole & 2003-2008 & $\begin{array}{c}17.7^{\wedge} \\
(8.5,27.7)\end{array}$ & 2008-2011 & $\begin{array}{c}-17.9 \\
(-48.8,31.5)\end{array}$ & 2011-2014 & $\begin{array}{c}17.0 \\
(-4.6,43.5)\end{array}$ & $\begin{array}{c}6.5 \\
(-3.9,18.0)\end{array}$ \\
\hline Podlasie & 2000-2008 & $\begin{array}{c}17.6^{\wedge} \\
(7.2,29.0)\end{array}$ & 2008-2011 & $\begin{array}{c}-33.0 \\
(-83.5,171.2)\end{array}$ & 2011-2014 & $\begin{array}{c}56.5 \\
(-10.8,174.5)\end{array}$ & $\begin{array}{c}10.8 \\
(-15.5,45.4)\end{array}$ \\
\hline Poland & 1999-2001 & $\begin{array}{c}53.6^{\wedge} \\
(19.6,97.4)\end{array}$ & 2001-2010 & $\begin{array}{c}15.3^{\wedge} \\
(13.7,16.9)\end{array}$ & 2010-2014 & $\begin{array}{c}5.8^{\wedge} \\
(0.9,11.0)\end{array}$ & $\begin{array}{c}17.1^{\wedge} \\
(13.5,20.8)\end{array}$ \\
\hline
\end{tabular}

$A P C$ - Annual Percentage Change, AAPC - Average Annual Percentage Change, $\mathrm{Cl}$ - confidence interval; $\wedge$ (APC/AAPC) is significantly different from zero at $\alpha=0.05 ; 95 \% \mathrm{Cl}(A P C / A A P C)$ is corresponding with $95 \%$ confidence intervals.

The age-standardised incidence rates of both invasive and in situ breast cancers showed increasing trends during the 1999-2014 period, with different patterns between analysed voivodeships (Tables 1, 2).

Time trends in invasive breast cancer incidence between 1999 and 2014 have varied slightly across the analysed data sources. The results of analyses indicated that most incidence rates increased within voivodeships and at the national level. On average, AAPCs varied from $1.6 \%$ to $7.9 \%$ annually, while in
Świętokrzyskie voivodeship AAPCs were remained below $0.9 \%$ annually (Figure 2).

For invasive breast cancer, ASRs for the 1999-2014 period, an increase (with no joinpoints) was observed in Podlasie, Mazovia, Opole, and Silesia voivodeships and at the national level in Poland (by 1.6\% to 2.1\% per year). In one voivodeship, there was one joinpoint - in Lublin (in 2001). In Lublin voivodeship, the ASRs increased by $24.4 \%$ during $1999-2001$ and by $1.8 \%$ per year between 2001 and 2014. In Świętokrzyskie 


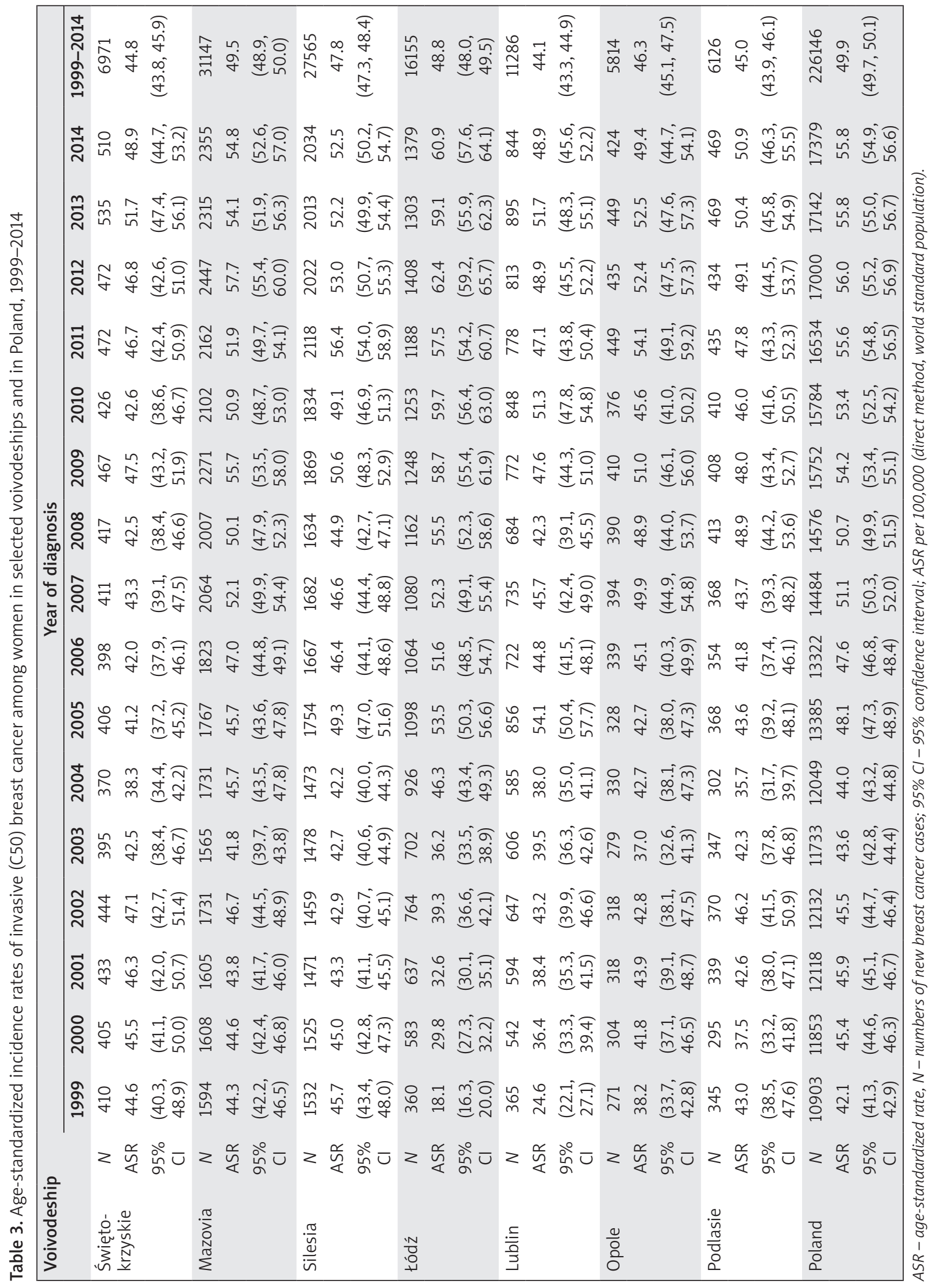




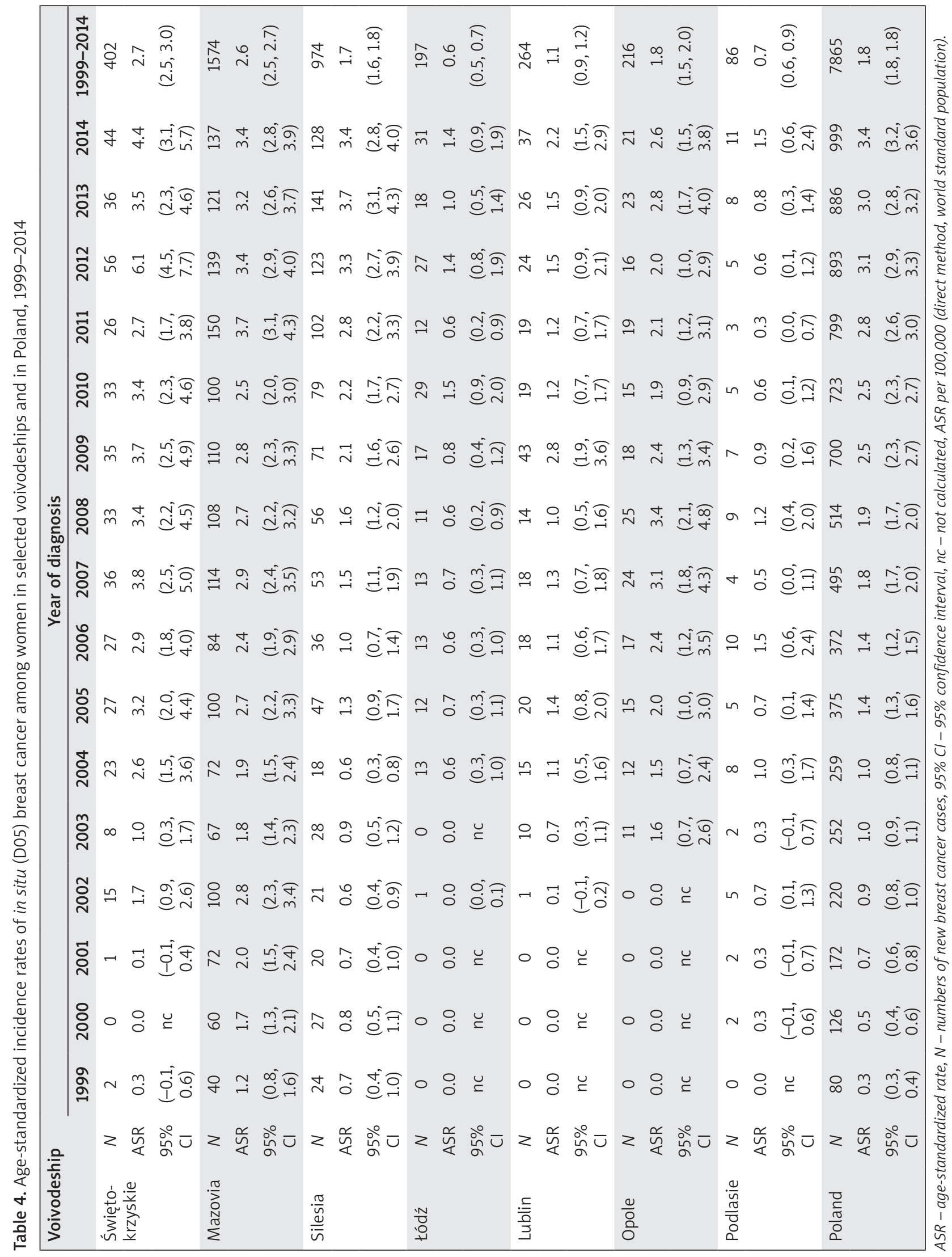




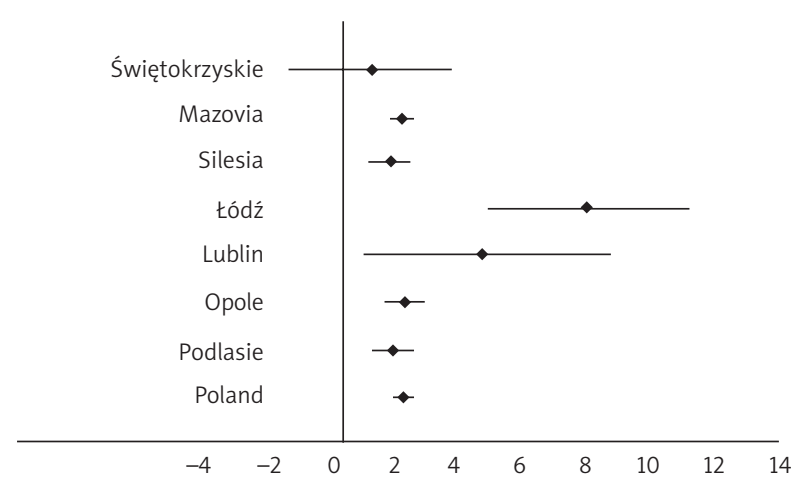

Figure 2. Average Annual Percentage Change (AAPC) of incidence of invasive breast cancer (C50) among women in selected voivodeships and in Poland, 1999-2014

voivodeship, there were two joinpoints - in 2001 and 2004. The ASRs increased by $4.4 \%$ between 1999 and 2001, decreased by $6.0 \%$ during 2001-2004, and then increased by $2.4 \%$ per year between 2004 and 2014 . Two joinpoints (three trends) were also found in Łódź Voivodeship - in 2001 and 2006. The ASRs of invasive breast cancer increased by $31.1 \%$ per year during 1999-2001. From 2001 to 2006 and 2006 to 2014 the ASRs also increased (by $9.4 \%$ and $1.8 \%$ per year, respectively).

Time trends in in situ breast cancer incidence among women during the study period (1999-2014) increased on average (AAPCs varied from 5.3\% in Mazovia to $22.8 \%$ in Świętokrzyskie voivodeship annually) and these changes were more dynamic than in the case of invasive breast cancer incidence trends (Figure 3).

The ASRs over the analysed period of time for in situ breast cancer and an increase (with no joinpoints) was observed only in Mazovia voivodeship (APC: 5.3\%; period of time 16 years) and Łódź voivodeship (APC: 8.2\%; period of time 11 years). Joinpoint analyses identified one joinpoint for the incidence series, separating two trends, in the rest of the voivodeships. In Świętokrzyskie (period of time 14 years) the ASRs of incidence increased by $114.8 \%$ per year between 2001 and 2004 (95\% CI: 34.7242.6), followed by an increasing trend from 2004 to 2014 by $3.9 \%$ per year.

In Silesia (period of time 16 years) the ASRs decreased from 1999 to 2002, and then they rapidly increased with a growing trend from 2002 to 2014 (APC: $17.2 \%)$

In Lublin voivodeship (period of time 13 years) the values of age-standardised incidence rates increased by $186.2 \%$ per year from 2002 to 2004 , and from 2004 to 2014 the trend of increase was $2.8 \%$ per year.

In Podlasie voivodeship (period of time 15 years) the ASRs increased by $17.6 \%$ from 2000 to 2008 , decreased by $33.0 \%$ from 2008 to 2011, then again they rapidly increased by $56.5 \%$ per year from 2011 to

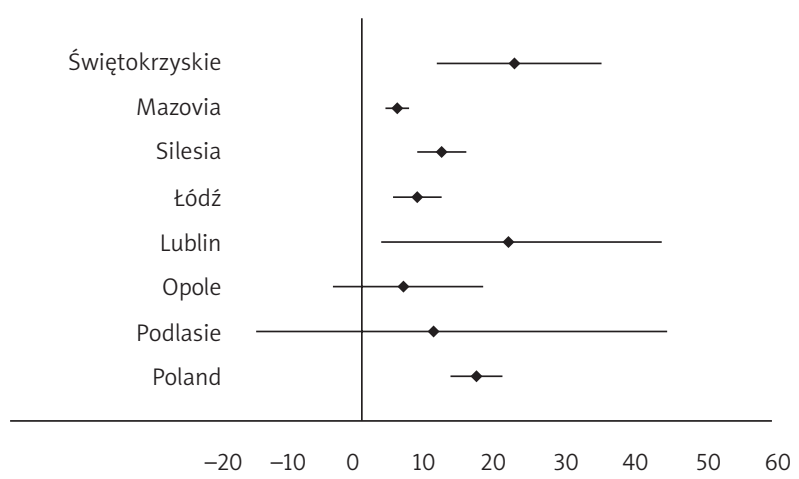

Figure 3. Average Annual Percentage Change (AAPC) of incidence of in situ breast cancer (D05) among women in selected voivodeships and in Poland in the analysed periods

2014. Two joinpoints were found at the national level (in 2001 and in 2010).

Opole voivodeship (period of time 12 years) had two joinpoints - in 2008 and 2011. The values of ASRs increased by $17.7 \%$ per year from 2003 to 2008, decreased by $17.9 \%$ per year between 2008 and 2011, then increased by $17.0 \%$ per year from 2011 onwards. The ASRs at the national level (in Poland) showed an increasing pattern. The increased of $53.6 \%$ per year was observed between 1999 and 2001, 15.3\% per year from 2001 to 2010, and 5.8\% between 2010 and 2014 .

\section{Discussion}

This is the most comprehensive descriptive study on breast cancer incidence in Poland that includes the examination of trends within voivodeships. The AAPCs indicate an overall increase in invasive and in situ breast cancer rates in Poland overall and within each of the voivodeships from 1999 to 2014. In Poland overall, incidence rates of invasive breast cancer in particular have significantly risen within the years 1999 to 2014, although the largest APCs have occurred prior to 2001. For voivodeships with joinpoints, the APC of invasive breast cancer incidence rates has consistently decreased, and for in situ breast cancer it has increased, probably reflecting the effects of breast cancer screening.

Incidence trends vary within each voivodeship. Since 2004 Łódź voivodeship has had the highest invasive breast cancer incidence rate, while Świętokrzyskie Voivodeship has had the highest in situ breast cancer incidence rate in the analysed periods of time. Łódź and Lublin voivodeships had the largest increase in situ and invasive breast cancer incidence rates.

An increase in breast cancer incidence rates was expected after implementation of the screening program in Poland. It was also observed in an earlier study by Botha et al. of 16 European countries that had adopted mammography screening in the 1980s [14]. The estimated APC ranges from $0.8 \%$ to $2.8 \%$ in 
six 'screened' countries during pre-screening years, and from $1.2 \%$ to $3.0 \%$ in 10 'non-screened' countries [14]. Breast cancer incidence increased between 30\% and $40 \%$ from the 1970 s to the 1990 s in most countries, with a visible increases among women aged 50 years and older. Breast cancer incidence rates are definitely higher in developed countries in comparison to developing countries, which is caused by distinct use of screening mammograms, discrepancies in lifestyle, and genetic factors [15].

With regards to breast cancer, Poland has historically had a high mortality-to-incidence ratio. The low incidence of breast cancer, in addition to the high mortality rate, low 5-year survival rates, and low morbidity are all an indication of ineffective primary cancer prevention campaigns, early detection, and treatment per se [16]. A similar situation also exists in other, recent members of the European Union, including Baltic countries, Bulgaria, and Romania. Among those countries, only Poland has implemented the National Programme of Cancer Prevention. One of the main goals of the National Health Programme in Poland was to increase early diagnosis and effectiveness of treatment of breast cancer [17]. The National Health Programme was beneficial in increasing the awareness of breast cancer prevention in Poland since its implementation [18]. From 1998 to 2001, the proportion of Polish women undergoing screening mammography nearly tripled from $10 \%$ to $28 \%$ [19]. One year after the accession of Poland into the European Union (EU), the Polish government enacted the bill implementing the National Programme Against Cancer Diseases (NPACD) for the years 2005-2010. In addition to increasing early detection of breast cancer, the goals of the NPACD included adopting diagnostic standards according to the EU [20].

On the other hand, mortality rates undergo gradual reductions. Increasing breast cancer incidence and a stable mortality trend shows the improvement of detection and treatment. During the last decade, an improvement of survival rates was observed in Poland, from $62 \%$ to $75 \%$.

According to the observed trends in Poland and in selected voivodeships, breast cancer trends increased overall, although the trend was not consistent across all voivodeships. As the wealthiest and most urban voivodeship in Poland, Mazovia has the highest incidence rates of both invasive and in situ breast cancers. This is consistent with other studies, which have also found higher breast cancer rates in the urban population [21]. Conversely, the lowest incidence of breast cancer was found in Podlasie, Lublin, and Świętokrzyskie voivodeships among women aged $65+$ years. The abovementioned regions are rural and during last 20 years there have been no large factories or industry.

Likewise, health benefits payer has presented results that indicate an increase in breast cancer 5 -year survival rates in the years 2005 to 2008, but there are huge differences in individual voivodeships - from $66 \%$ to $79 \%$ and from $75.3 \%$ to $82.4 \%$ [22, 23]. Significant differences in results, methods, and costs may show the usage of various procedures and financial models. Considering the relationship between therapeutic effects and bearing costs, women with breast cancer have no equal access to the health care system, depending on their place of residence.

Disparities among voivodeships may be the result of environmental and cultural causations. There are some reasons for the increasing health hazard for cancer diseases: improper nutrition (excessive animal fat intake and low vegetable and fruit intake), excessive alcohol intake, poor physical activity, exposure to carcinogens in the workplace, lack of awareness of cancer danger, and community aversion to screening programs [24]. There is a need to develop health education, smoking restrictions, and to create appropriate dietary habits and reduce harmful carcinogenic conditions in the workplace and residence. Differences in patterns probably reflect changes in lifestyle risk factors such as reproduction behaviours and diet but cannot exclude the possibility of higher screening mammography rates and early detection in some voivodeships [25].

Limitations of our study are similar to other studies using data based on registries. These include analysis of data only for women who have visited a doctor. Also, trend analysis is not sufficient to determine the cause of the increase. Relevant and established breast cancer risk factors, such as nulliparity, obesity, lack of exercise, young age at menopause, long-term use of hormone replacement therapy, personal family history, and others, could not have been included in this analysis. Thirdly, histological classifications of breast cancer have changed over the course of 14 years, which may result in some outcome misclassification.

This study also has several strengths. We covered 16 years of breast cancer incidence in Poland, which spans the course of political, economic, as well as cultural and lifestyle changes that have occurred. The use of a joinpoint regression analysis using NCR data allows us to obtain an objective representation of breast cancer incidence as well as a direct comparison across regions of varying geographical locations within Poland. Lastly, this is the only study to analyse cancer incidence rates across different voivodeships within new EU member countries and provides a broad insight as to the circumstances surrounding mediumlevel incidence rates in similar countries.

\section{Conclusions}

In situ and invasive breast cancer incidence rates in Poland increased between 1999 and 2014. The rise in invasive breast cancer incidence rates in Poland is largely due to improved screening as well as a shift in 
lifestyle risk factors after the accession of Poland into the EU in 2004. The APCs have slowed since 2004 in each voivodeship but not in Poland overall. It remains uncertain if breast cancer incidence rates will continue to increase or stabilise over time. It will be very important to monitor breast cancer incidence so that resources can be put into place to identify voivodeships most in need of mammography screening and breast cancer awareness. Increased public awareness of the benefits of mammography screening, self-examination, and risk factors will be important in reducing breast cancer rate disparities between Poland and its neighbouring European Union states.

\section{Conflict of interest}

The authors declare no conflict of interest.

\section{References}

1. Yip CH, Buccimazza I, Hartman M, Deo SVS, Cheung PS Improving outcomes in breast cancer for low and middle income countries. World J Surg 2015; 39: 686-692.

2. Beiki O, Hall P, Ekbom A, Moradi T. Breast cancer incidence and case fatality among 4.7 million women in relation to social and ethnic background: a population-based cohort study. Breast Cancer Res 2012; 14: R5.

3. Ferlay J, Soerjomataram I, Ervik M, Dikshit R, Eser S, Mathers C. GLOBOCAN 2012 v1. 0, cancer incidence and mortality worldwide: IARC CancerBase No. 11. International Agency for Research on Cancer, Lyon [online] [cited 2014 04.05]. Globocan Iarc Fr.

4. Jokiel M. Social aspects of breast cancer early detection after introduction of population screenings in Poland. Przegl Epidemiol 2008; 63: 443-447.

5. Liong YV, Hong GS, Teo JG, Lim GH. Breast ductal carcinoma in situ presenting as recurrent non-puerperal mastitis: case report and literature review. World J Surg Oncol 2013; 11: 179

6. Survival Analysis 2000 - 2007 [online] [cited: 2015 10.30]. Available from: https://w3.iss.it/site/EU5Results/forms/ SA0007.aspx.

7. Sytuacja demograficzna osób starszych i konsekwencje starzenia się ludności Polski w świetle prognozy na lata 2014 2050. Warszawa: Główny Urząd Statystyczny 2014; 1-43.

8. Demographic Yearbook of Poland 2014 [online] [cited: 2015 10.30]. Available from: http://stat.gov.pl/en/topics/ statistical-yearbooks/statistical-yearbooks/demographic-yearbook-of-poland-2014,3,8.html

9. Raporty Krajowego Rejestru Nowotworów [online] [cited: 2015 03.20]. Available at: http://onkologia.org.pl/raporty/.

10. Didkowska J, Wojciechowska U, Zatoński W. Nowotwory złośliwe w Polsce w 2011 roku. Cent Onkol Warszawa 2013 [online] [cited: 15 marzec 2015]; Available at: http:// onkologia.org.pl/wp-content/uploads/COI_Nowotwory2013 web.pdf.

11. Didkowska J, Wojciechowska U, Zatoński W. Prognozy zachorowalności i umieralności na nowotwory złośliwe w Polsce do 2025 roku. Centrum Onkologii - Instytut im. M. Skłodowskiej-Curie, Warsaw 2009.

12. Kim HJ, Fay MP, Feuer EJ, Midthune DN. Permutation tests for joinpoint regression with applications to cancer rates. Stat Med 2000; 19: 335-351.
13. Clegg LX, Hankey BF, Tiwari R, Feuer EJ, Edwards BK. Estimating average annual per cent change in trend analysis. Stat Med 2009; 28: 3670-3682.

14. Botha JL, Bray F, Sankila R, Parkin DM. Breast cancer incidence and mortality trends in 16 European countries. Eur J Cancer 2003; 39: 1718-1729.

15. Althuis MD, Dozier JM, Anderson WF, Devesa SS, Brinton LA. Global trends in breast cancer incidence and mortality 1973-1997. Int J Epidemiol 2005; 34: 405-412.

16. Curado MP. Breast cancer in the world: incidence and mortality. Salud Pública México 2011; 53: 372-384.

17. Department of Medical Statistics, National Institute of Hygiene. Health programme for years 1996-2005 [online] [cited: 2015 08.06]. Available at: http://www.medstat. waw.pl/nhp_p/1_p.html.

18. Hendrick RE, Smith RA, Rutledge $3^{\text {rd }} \mathrm{JH}$, Smart CR. Benefit of screening mammography in women aged 40-49: a new meta-analysis of randomized controlled trials. J Natl Cancer Inst Monogr 1996; 22: 87-92.

19. Syczewska-Weber K, Rucinski P. The main challenges of Polish oncology. Public Health Rep 2008; 123: 655-63.

20. Act of 1 July 2005 on Establishing the Multi-Year "National Cancer Control Programme" [online] [cited 2015 08.06]. Available at: http://www.epaac.eu/from heidi_wiki/Poland_Establishing_the_Multi-Year_National_Cancer_ Control_Programme_English.pdf.

21. Krzyzak M, Maslach D, Juczewska M, Lasota W, Rabczenko D, Marcinkowski JT, Szpak A. Differences in breast cancer incidence and stage distribution between urban and rural female population in Podlaskie Voivodship, Poland in years 2001-2002. Ann Agric Environ Med 2010; 17: $159-162$

22. Kozierkiewicz A, Topór-Mądry R, Śliwczyński A, Pakulski M, Jassem J. Skuteczność i koszty leczenia raka piersi w Polsce: podejście regionalne. Nowotw J Oncol 2014; 64: 24-32.

23. Herman K, Śliwczyński A, Wysocki WM. Wyniki, metody i koszty leczenia raka piersi w Polsce (w latach 20052007). Nowotw J Oncol 2014; 64: 33-39.

24. Zatoński W, Przewoźniak K. Ograniczanie zachorowalności i umieralności z powodu chorób nowotworowych. [In:] Zdrowie publiczne i polityka ludnościowa. Rządowa Rada Ludnościowa. Szymborski J (ed.). Warsaw 2012; 78-89.

25. Ferlay J, Steliarova-Foucher E, Lortet-Tieulent J, Rosso S, Coebergh JW, Comber H, Forman D, Bray F. Cancer incidence and mortality patterns in Europe: estimates for 40 countries in 2012. Eur J Cancer 2013; 49: 1374-1403.

\section{Address for correspondence:}

\section{Paweł Macek MD, PhD}

Department of Epidemiology and Cancer Control

Holycross Cancer Centre

ul. Artwińskiego 3, 25-734 Kielce, Poland

Phone: +48 603161576

E-mail: pawel.macek@gazeta.pl 